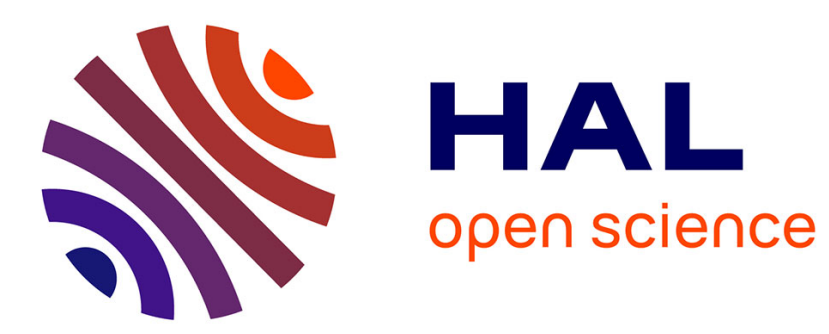

\title{
Thirty Years of Research on Gay Men and HIV Prevention in France: A Narrative Review of the Literature
}

Gabriel Girard, Veronique Doré

\section{- To cite this version:}

Gabriel Girard, Veronique Doré. Thirty Years of Research on Gay Men and HIV Prevention in France: A Narrative Review of the Literature. Archives of Sexual Behavior, inPress, 10.1007/s10508-018-11631. halshs-01721184

\section{HAL Id: halshs-01721184 \\ https://shs.hal.science/halshs-01721184}

Submitted on 1 Mar 2018

HAL is a multi-disciplinary open access archive for the deposit and dissemination of scientific research documents, whether they are published or not. The documents may come from teaching and research institutions in France or abroad, or from public or private research centers.
L'archive ouverte pluridisciplinaire HAL, est destinée au dépôt et à la diffusion de documents scientifiques de niveau recherche, publiés ou non, émanant des établissements d'enseignement et de recherche français ou étrangers, des laboratoires publics ou privés. 


\section{Thirty Years of Research on Gay Men and HIV Prevention in France: \\ A Narrative Review of the Literature}

\section{Co-authors:}

- $\quad$ Gabriel Girard (PhD), Institut de Recherche en Santé Publique de l'Université de Montréal, Montréal, Canada: Gabriel.girard.info@gmail.com

- Véronique Doré $(\mathrm{PhD})$, Agence Nationale de Recherche sur le Sida et les hépatites virales, Paris, France: Veronique.dore@anrs.fr

Compliance with Ethical Standards: The translation of this article was funded by ANRS.

Conflicts of interest: Gabriel Girard was funded by ANRS (PhD grant 2006-2009; post-doc grant 2014-2016). Véronique Doré works as social science head department at ANRS. This article reflects only the views of the two authors, and not the views of ANRS.

Ethical approval: This article does not contain any studies with human participants performed by any of the authors.

\section{ABSTRACT}

Research on homosexuality and HIV/AIDS in the social sciences has evolved into a vast and multi-form field of study since the beginning of the epidemic in the Global North. Studies from France in this domain have remained relatively unknown at the international level. This article offers a narrative review of publications that resulted from research on homosexuality and HIV/AIDS, from 1985 to 2016. It offers an analysis of how the constitution of a field of research conditions the ways scientific questions are asked (and answered). This epistemological concern is addressed through a sociohistorical contextualization of the main issues surrounding prevention and how they have been addressed by researchers in France. A review of French publications on 
HIV prevention among gay men reveals certain specificities. In terms of the social science disciplines, psychology and psychoanalysis are much less present in this domain, whereas epidemiology, sociology, and anthropology are the most represented. The works analyzed in this article also reveal the circulation and local adaptations of risk categories imported from the English-speaking world, such as "relapse" and "bareback." Regardless, research on HIVprevention in France largely evolved contemporaneously in the same way that it did elsewhere.

Keywords: HIV/AIDS, Gay and bisexual men, France, prevention, sexual orientation 


\section{INTRODUCTION}

Is there such a thing as a "French approach" to research in the social sciences on HIV prevention? When asked in this way, the answer to this question may seem obvious: history has demonstrated that HIV/AIDS struck gay communities all over the world with the same force. Moreover, the issues raised by barebacking, rapid HIV testing, and Pre-Exposure Prophylaxis (PrEP) arise in a variety of contexts. Their emergence is influenced by research priorities. The ways that researchers in the social sciences have conceived their studies on HIV prevention, however, have been heavily influenced by the academic and political contexts surrounding their work. In France, HIV/AIDS research has been structured by ad hoc funding agencies. The French Agence Nationale de Recherche sur le SIDA - France REcherche Nord\&Sud Sida HIV Hépatites (ANRS) [National AIDS Research Agency] has played a key historical role. This agency, created in 1988 , has funded various studies in the social sciences and public health on topics such as virology, vaccines, immunology, treatment, etc., since the late 1980s. It has also contributed to the creation of a distinct field of research through committees called Actions coordonées [Coordinated Actions], and has provided support to the scientific committees of the funded studies and trials. Since 2005, Sidaction (private organization) has also funded HIV research in the social sciences ${ }^{1}$.

The objective of this article is to offer a critical analysis of the research on HIV prevention among gay men that was financed by ANRS in France, from 1988 to 2016. This work involves contextualizing the emergence of different research questions in France and how they have been approached by researchers in the social sciences. This article offers a review of the key moments

${ }^{1}$ Sidaction is primlarily a public event started in 1994 for raising awareness and collecting funds for AIDS. It donates important sums to AIDS organizations and research in more than 20 countires. 
in the "problematization" of prevention among gay men in the field of HIV research in France (Foucault, 1998). Foucault defined "problematization" as "what one does, the motion by which one detaches from it, establishes it as an object, and reflects on it as a problem." Reflecting on controversial moments in the history of HIV/AIDS in France, this article provides a sociological perspective on the complex relationships between scientists, public health authorities, and activists that have contributed to shaping a distinct field of research. In doing so, we acknowledge that AIDS research funding has also contributed to the development of studies on sexuality and homosexuality at large. The lens of "sexual risk" has profoundly and durably affected this field of research, as elsewhere in the World (Gagnon, 1988). However, in this article, our interest is mainly on the context of HIV prevention among gay men, not how HIV prevention has delineated the research agenda on homosexual realities.

This article also offers an analysis of the development and unique characteristics of research on HIV prevention among gay men in France. Although social science research conducted in France has contributed to shaping European policy on the issue (Bochow et al., 1994), its development and evolution remain relatively unknown to a non-francophone readership. Two aspects in particular are explored. First, research on homosexuality and HIV/AIDS were developed in a context influenced by French republican universalism, where the notion of community is considered suspect (Caron, 2001). This ideological and political constraint has shaped the orientation of scholarly work on homosexual sociability, risk, and mobilization around safer sex. The two authors of this article are not in a neutral position vis-à-vis the ANRS. Girard is a sociologist whose research projects have been evaluated, and sometimes funded, by the agency. Doré has been working for the Agency's social sciences research department for nearly 25 years. Doré provided access to lists of funded projects and published articles or reports that are 
otherwise unavailable to the general public. ANRS management, however, did not intervene in the writing of this narrative review.

\section{METHOD}

This article is based upon a narrative literature review of publications (reports, articles, and books) on homosexuality and HIV/AIDS that were financed by the ANRS between 1988 and 2013 (more than 500 references). The list of financed projects was produced using data provided by the ANRS. In total: 16 doctoral scholarships and 36 research projects were financed during the period studied. Research on sexuality in the general population was also included because it contains information on sexual behavior among homosexuals: Comportements sexuels des français [Sexual behaviour in France] in 1992 and 1996; Enquête sur la sexualité des jeunes [Inquiry into youth sexuality] in 1994; and several of the knowledge, attitudes, beliefs, and behaviors studies. This article also takes into account publications that were not financed by the ANRS in order to gain a broader understanding of the history and context surrounding research conducted on HIV/AIDS in the country during this period. Notably, we also examined research projects that preceded the creation of the ANRS in 1988.

The selection of relevant references for the article was based on two objectives: (1) to represent a diversity of reseach interest in the field; (2) preferably to select peer-reviewed articles, books, and book chapters. We consulted research reports when no other publications were available. A total of 88 references were the basis of this bibliographic research. Most relate to period between 1988 and 2016. For ethical and practical reasons, we did not analyse the scientific committee's reports. Which means that we did not explore the selection process, nor the rejected projects. 
This narrative review brings to light different historical periods, which are characterized by the predominance of certain research questions. This article is based on a survey of publications in order to historically contextualize research on homosexuality and HIV/AIDS in France.

\section{RESULTS}

\section{5-1991: The Pioneer Period}

Starting in 1984, the collaboration between the sociologist Michael Pollak and his colleague Marie-Ange Schiltz marked the beginning of a major collaboration in the history of HIV/AIDS research in France:

We were conscious of the urgency of the situation and the tragedy that was about to unfold (...) Flexibility in the means used to access empirical information, rapidity of production, and of communication of results to health administrations, other researchers, associations, and homosexuals: these were our rules of conduct, and these were the conditions of our collaboration. (Schiltz, 2010).

Thus, there is no doubt that the "Enquêtes Presse Gay" [Gay Press study], relayed by the community newspaper Gai Pied Hebdo, would become an important reference for understanding the epidemic among young gay men in France. In 2011, the study marked its 14th edition and for the first time integrated a specific lesbian component. A symbol of the continuity of research in France on HIV and homosexuality, the "Enquêtes Presse Gay" (EPG) paved the road to a diversified field of research that the creation of a national AIDS research agency (ANRS) in 1988 helped structure.

Researchers did not wait for the creation of the ANRS to begin conducting social science studies on HIV/AIDS, particularly within the homosexual population (Pollak \& Schiltz, 1987). At the time, the scientific community was confronted with some complex issues. The advent of HIV/AIDS brought to light the lack of sociological and demographic knowledge about sexuality 
in France, and even more so about the gay community, massively afflicted by the epidemic. Yet, understanding lifestyles and sexualities, notably among gay men, was indispensible for adapting activism among associations and creating public policy. Within this context, the EPG studies initiated in 1985 were financed by the ANRS, an always reliable source of funding, starting in 1988. The first studies, however, were almost exclusively dedicated to gay lifestyles; research on health among lesbians and trans people would not emerge until the 2000s.

But researchers were also interested in measuring the risks of stigmatization of the affected groups. Hence, in 1987, the first studies were conducted in the general population on their opinions and beliefs regarding HIV/AIDS. This research appeared before the studies on knowledge, attitudes, beliefs, and behaviors (KABP) towards HIV/AIDS that have been conducted regularly since. For their part, the EPG studies have been able to document the very rapid adaptation of gay men to the epidemic (Pollak, 1988). This adaptation manifested itself in several different ways: for example, lowering the number of sexual partners or avoiding anal penetration. But the large-scale adoption of the condom as a prophylactic was no doubt the most significant transformation of the 1980s. Prevention became an unavoidable reality, and the condom became the symbol of the mobilization of gays against HIV/AIDS. The early years of social science research into the disease were marked by an objectification, by researchers and public health authorities, of risky sexual practices. Researches claimed that these studies were meant to help public health authorities reach those most susceptible to contracting the disease. However, use of the notion of what public authorities termed "risk groups" caused some controversy, and led most researchers to focus on "risk behaviors." This context has contributed to the problematization of HIV prevention in France as a predominantly behavioral issue, in order to avoid the stigmatization of sexual minorities (Calvez, 2004). 
In terms of public health, the first years of the epidemic were marked by the development of an emergency response to HIV/AIDS. This response came first from the medical field and the gay community (Dodier, 2003). The successive creation of Vaincre le Sida in 1983, AIDES in 1984, Arcat-SIDA in 1987, and Act Up-Paris in 1989 demonstrate the role that those most affected by the disease intended to occupy in the fight against it, alongside doctors and researchers. But the response to the epidemic also progressively involved public health officials and government institutions, which led to the creation, in 1988, of the Conseil National du SIDA (responsible for guiding government authorities on ethical questions), the Agence Française de Lutte contre le Sida (responsible for promoting prevention), and the Agence Nationale de Recherche sur le Sida (responsible for research) (Pinell, 2002).

In the years that followed, important sums of money were allocated to conduct studies about sexual behaviors among the general population, which helped bring to light prevention practices: a study on general sexual behavior (Enquête sur l'Analyse des comportements sexuels en France), in 1992 (Bajos, 1997; Bajos, Bozon, Ferrand, Giami, \& Spira, 1998); a study on youth sexuality (Enquête sur la sexualité des jeunes), in 1994 (Lagrange \& Lhomond, 1997) and, in 1995, a study on sexuality in the French Antilles and French Guyana (Enquête sur la sexualité aux Antilles et en Guyane) (Giraud, 1997). The data concerning gay and bisexual men were the subject of specific analyses, but the results must not be overstated because of the small sample size. A new study contextualizing sexuality in France (CSF) was conducted in 2006 (Bajos \& Bozon, 2008; Bajos et al., 2010).

As in other countries in the Global North, research on homosexuality and HIV/AIDS was developing somewhere between the intersection of sociology and epidemiology. Yet, although critical perspectives (cultural studies, anthropology) played an important role in the creation of knowledge about HIV/AIDS (Altman, 1984; Patton, 1989; Treichler, 1987) in the English- 
speaking world, these approaches were very rarely employed in the first years of the epidemic in France.

\section{1-2000: Understanding Cultures of Prevention}

The beginning of the 1990s was marked by a proliferation of sociological and anthropological studies about HIV/AIDS, both in the form of academic research as well as action and participatory research, notably among gay communities (Giami \& Schiltz, 1996; Mendès-Leite \& de Zwart, 2000). Almost 10 years after the beginning of the epidemic, there was a need to address the limitations of prevention: how does one explain, for example, that gay men continue to spread the virus despite all of the information available and prevention campaigns? Questions like this one seem all the more pernicious when one considers the alarming new phenomenon in the world of prevention: the "relapse" (Davies, 1992), and the changes in preventive practices among men who already use condoms (Kippax, Crawford, Davis, Rodden, \& Dowsett, 1993; Schiltz, 1998). During this period, French debates on HIV prevention were largely centered around the controversial notion of sexual promiscuity. In the early 1990s, having a high number of sexual partners was the factor most associated with the risk of contracting HIV. Qualitative researchers working in the field with at-risk populations opposed this approach because they feared homophobic backlash against sex-clubs and saunas. Researchers notably highlighted the diversity of preventive strategies among gay men and the high potential of gay sociability for the promotion of HIV awareness (Mendès-Leite, 1995).

The year 1994 marked the peak of the epidemic in France, with a record number of new cases of AIDS (5781) and deaths (4205). From then on, research diversified in order to gain a better understanding of homosexual cultures around prevention (Calvez, Souteyrand, \& Schiltz, 1996). The "rationales of prevention" were the subject of numerous qualitative studies. They involved 
researching the different modalities of risk perception and analysed forms of "imaginary protection" (Mendès-Leite, 1998) that existed among gays. The decline of preventive practices was examined through a psychological lens (Lisandre, 1996), as well as by using the data from the EPG studies (Adam \& Schiltz, 1995). There was a growing consensus that the limitations of the condom-centered prevention paradigm revealed the need for a multifactorial approach. At the same time, living with HIV (Pierret, 1996) and the sexuality of HIV-positive people (Lert \& Souteyrand, 1999) became major subjects of interest.

Studies have also examined sites of sexuality and of prevention, such as cruising sites (Gaissad, 2005; Proth, 2002) and backrooms (De Busscher, Mendès-Leite, \& Proth, 1999). The "margins" of the gay community have also been the subject of research, notably on bisexuals (Deschamps, 2002), and sex workers (Laurindo da Silva, 1999). Lastly, the community reaction of gays against HIV/AIDS has been the subject of analyses and sociohistorical studies (Broqua, 2006; Dodier, 2003; Pinell, 2002; Welzer-Lang, Le Talec, \& Tomolillo, 2000).

For those involved in the fight against HIV/AIDS, maintaining the safer sex norm became a major challenge (Kippax \& Race, 2003). This was especially the case after 1996, when the introduction of antiretroviral treatments partially changed the paradigm, which would potentially lead to "therapeutic optimism," which in turn could stem prevention efforts (Adam, 2003; Lert, 2000). At the same time, during the 1990s, the legal situation changed for homosexuals. The establishment of the Pacte Civil de Solidarité (PaCS), a civil union contract open to non-married couples, represented major social recognition of homosexuality in French society, the adoption of which HIV/AIDS organizations had actively fought for. This period was characterized by the struggle for social recognition of homosexuality in France. In terms of "problematization" of HIV prevention, the link between structural homophobia and individual risk-taking was the dominant political and intellectual framework for researchers, activists, and public health authorities. 
Furthermore, HIV/AIDS was then thought of as a "political disease" because it revealed social inequalities, as demonstrated by the various studies on activism surrounding the epidemic. With the advent of treatment, normalization of HIV/AIDS (Rosenbrock et al., 2000) reoriented research questions. The coming period would be marked by the recognition of an upsurge in risky sexual practices among gay men at the international level.

\section{0-2007: A New Relationship to Risk?}

In 2000, for the first time, the EPG documented a significant increase in risky sexual practices among gay men (Adam, Hauet, \& Caron, 2001), affirming the trend observed in other countries around the world (Stall, Hays, Waldo, Ekstrand, \& McFarland, 2000; Van de Ven, Prestage, French, Knox, Kippax, 1998). At the same time, this caused controversy in the gay community; some gay men chose to have sex without condoms and reclaimed the to right to do so (Girard, 2013). "Barebacking," despite being practiced by a minority of gay men, would monopolize the attention of researchers for the decade to come. In the French context, barebacking became highly controversial in the late 1990s. Well-known personalities such as Didier Lestrade (journalist and founder of Act Up-Paris) and Guillaume Dustan (famous author who reclaimed the right to bareback) would often represent opposing sides of the debate in public. Some scientific research was funded to explore the subject (Le Talec, 2007; Léobon \& Frigault, 2007), but those studies have been relatively ignored outside French borders, as evidenced by the lack of French references in Berg's (2009) literature review on barebacking. Nearly 20 years after the beginning of the epidemic, the ANRS published Homosexualités au temps $d u$ SIDA, a study that examined the evolution of prevention among gay men (Broqua, Lert, $\&$ Souteyrand, 2003). The researchers depicted a group living through a social and identity crisis in the form of a "paradoxical" double normalization (De Busscher \& Broqua, 2003): the 
experience of homosexuality had become diversified, without having become completely normalized; and although HIV had become a lot less frightening, it remained a reality that was ingrained in the gay community. Prevention, as it had been imagined for two decades, was revealing its limitations.

In the mid-2000s, prevention among gay men became a battleground. Unable to agree on how to react to the rise of barebacking, HIV/AIDS organizations were also divided over the notion of "réduction des risques sexuels" (RdR), or risk reduction, elaborated by the community organization $\operatorname{AIDES}^{2}$. For this association, it was a matter of offering alternative strategies to gay men who were abandoning condom use, such as pulling out before ejaculation. However, the RdR approach encountered opposition from other stakeholders, namely Act-Up Paris, who saw in it a challenge to the prevention norm. Meanwhile, epidemiological studies continued to demonstrate the trend all over the world (Elford, 2006): condom use with occasional partners had again gone down (Velter, 2007), and the multiplication of social media applications for gay men online appeared to have facilitated the negotiation of unprotected sex (Léobon, Velter, Engler, Drouin, \& Otis, 2011). Did this data reveal a new relationship to risk? This was the central question at the conference organized by the ANRS in September 2005 (Bozon \& Doré, 2007). It was an opportunity to explore new questions, notably about the links between gay conjugality and prevention (Courduriès, 2007; Lerch, 2007), but also to critically examine the use of the notion of barebacking (Le Talec, 2007). The data from the ANRS-VESPA study, conducted among those afflicted by the disease, also contributed to a better understanding of the quality of participants' sex lives and other social factors associated with risky behaviour in this population (Bouhnik et al., 2006; Lert, Sitta, Bouhnik, Dray-Spira, \& Spire, 2010). AIDES.

\footnotetext{
${ }^{2}$ Girard was part of some public debates around barebacking issues, both as researcher and as a member of
} 
During this period, new research emerged on subjects such as barebacking (Girard, 2013; RojasCastro et al., 2012; Rojas Castro, \& Girard, 2015), co-infection with HIV and hepatitis C (Le Talec, 2013; Marcellin et al., 2015), as well as gay men and their relationship to pornography (Vörös, 2014), drug use (Fournier \& Escot, 2010; Gaissad, 2013), and strategies of risk reduction (Lorente et al., 2012; Velter, Bouyssou-Michel, Arnaud, \& Semaille, 2009). This period also saw the development of seminal research on Africa and migrations of "men who have sex with men" between African countries and France (Awondo, Geschierer \& Reid, 2012; Broqua, 2013; Gning, 2013; Wade et al., 2010).

The beginning of the 2000s was marked, at the international level, by concern about risk-taking among gay men and strategies to reduce it (Jin et al., 2009). As elsewhere, French research addressed this issue. We observed two unique aspects of the French context. Firstly, in France, there had been little research on drug use and HIV within gay communities. Secondly, the conflicts among HIV/AIDS organizations about risk reduction delayed the development of research on this question. The French context was hence characterized by a strong politicization of debates around risk, which was a result of the way that HIV/AIDS activism manifested itself in the country.

This context may explain why the problematization of HIV prevention was so dominant at this time. Academic works on barebacking, with varying degrees of criticism on the practice, have been numerous in the English-speaking world. In France, with the exception of a few of the aforementioned studies (mainly qualitative and exploratory), research funds have been oriented towards the epidemiological description of risk-reduction strategies and risk factors. This can be interpreted as a choice, whether intentional or not, to approach HIV prevention as a depoliticized issue. In doing so, those providing research funding move away from the most radical options (carried out by Act Up) on condom-centered prevention, and support AIDES's approach of harm 
reduction, seen as more pragmatic. But this orientation can also be seen as a reluctance, by many scientists, to study the diversity of gay sex cultures (Girard, 2016).

\section{Since 2007: The Biomedicalization of Prevention?}

Although HIV-prevention strategies had always been based on changing individual and collective behaviors, the end of the 2000s saw an important transformation in this domain with the introduction of the biomedical approach, for which gay men were the targeted demographic. Beginning in 2007, rapid HIV-testing became an issue that incited research and action, and HIV/AIDS organizations hoped to use this tool. Then a new development emerged: AIDES got directly involved in research as a community stakeholder (Champenois et al., 2012; Lorente et al., 2013). The ANRS's dépistage [testing] group was the result of this initiative. In 2011, after the encouraging results of the pilot run, the health ministry authorized activists to provide STI testing to the population.

In 2009, public health authorities asked F. Lert and G. Pialoux to coordinate an experts' report on new approaches to prevention. Its publication at the end of 2009, accompanied by recommendations, marked a turning point (Lert \& Pialoux, 2009). Although the report recalled the centrality of condoms in risk reduction strategies, it also acknowledged the preventive role of antiretrovirals: by reducing the viral load of HIV-positive people, the treatment reduced their infectiousness. The Lert-Pialoux Report hence opened the door for "combined prevention" (Hankins \& Zalduondo, 2010), which acts on three different levels: condoms, testing, and treatment. Afterwards, the approach was reproduced in experts' reports on HIV patient care. In France, as at the international level, the increased medicalization of prevention has been a game changer. Although disagreements over the subject persist, researchers and HIV/AIDS organizations agree on the need to widen and diversify the preventive options offered to gay men, 
notably in terms of testing (Greacen et al., 2012). New data on the incidence (Le Vu et al., 2010), prevalence (Velter, 2013), and evolution of risky behaviors remains worrisome. Since 2003, new diagnoses among gay men are on the rise. They account for $43 \%$ of new infections in 2015, and more than 2,500 cases (Cazein et al., 2016). According to Cazein et al., France is the European country with the highest rates of HIV-infection among gay men.

It is in this context that several studies were initiated, among them:

The Prévagay study in 2009, which showed high level of HIV prevalence in the Parisian gay bars, sex-clubs, and saunas, and that $20 \%$ of infected men ignored it (Velter et al., 2013; Semaille et al., 2013);

- $\quad$ The new edition of the EPG in 2011, which showed another increase in anal intercourse without condoms, notably among HIV-positive gay men (Velter, 2013);

- $\quad$ The ANRS-VESPA2 study on the living conditions and sexuality of people living with HIV, in 2011 (Marsicano et al., 2014);

The Evarist study, in 2011-2012, which showed the correlates of viral load variations in sperm (Goshn et al., 2014);

The ANRS-Ipergay trial on the effectiveness of Pre-Exposure Prophylaxis (PrEP), in demand by HIV-negative gay men who are most exposed to the disease. ANRS-Ipergay trial demonstrated the very high potential of an ondemand PrEP (Lorente et al., 2012; Molina et al., 2015).

The predominant problematization of HIV prevention in this period was characterized by tensions around biomedical prevention. The ANRS-Ipergay study drew criticism from members of the gay community, many of whom interpreted it as a drug-centered preventive response, and a renunciation of individual responsibility for one's behavior. But the emergence of PrEP and its 
support as a strategy of prevention by health authorities (January 2016) represented the apex of understanding of risk both as a preventable event and an issue of individual responsibility. Significantly, during recent years social science research funded by the ANRS has been largely incorporated into large-scale biomedical trials, and less autonomous. Thereby, the studies conducted since 2007 are more frequently based on quantitative methods and more systematically associate themselves with community organizations as research partners. In doing so, the critical distance required for a social sciences critique of biomedicalization becomes restrained.

\section{DISCUSSION}

The first years of research in social sciences on HIV/AIDS were undoubtedly influenced by the close intellectual and practical exchanges characteristic of an emerging research field. However, studies at the intersection of homosexuality and HIV/AIDS in France were influenced by a universalist dominant approach, which leaves little room for the study of sexual minorities in academia. In this context, social science research on homosexuality and HIV/AIDS has suffered from a dual disadvantage. It has remained insignificant in the academic field, having been eclipsed by epidemiological/public health studies, and by the reorientation of LGBT research beyond the domain of sexual health. Furthermore, the low number of regular academic positions in the field reinforces this structural fragility. More than 30 years after the first "Enquête Presse Gay" and 30 years after the creation of the ANRS, the concept of prevention has been transformed. New sexual health issues have gained visibility, as demonstrated by the studies on health among lesbians (Chetcuti et al., 2013) or the emergence of studies on the trans community (Giami \& Beaubatie, 2014). Furthermore, the development of research by community organizations has established their new role in this domain: in research, activists are implicated in every stage of the study and their expertise is 
recognized. With the inter-association collective $T R T 5$, the critical contribution of a large number of LGBT associations to the ANRS-Ipergay trial also bears witness to the gay community's interest in research on prevention. However, the reorientation of HIV research on prevention in the field of risk reduction and biomedical issues marks the last period of our study. Accompanying the growing pressure to produce peer-reviewed publications, these tendencies lead to a certain normalization of French research, but they also overshadow more qualitative and critical works.

Utilizing Foucault's analysis in terms of problematization, this study made it possible to highlight the intellectual and political conditions surrounding the development of research on HIV prevention in France. Such an approach underlines the importance, particularly with regards to HIV/AIDS research, of taking into account the debates between various actors and the context surrounding the production of scientific work. This perspective allows us to consider how public health authorities have attempted to understand, analyze, and thus also regulate the sexual behaviors of gay men. Our approach thus reveals that, although the biomedical understanding of HIV prevention is now dominant, it is the product of a history that is both scientific and political. However, our analysis admittedly has some limitations. First, it is based on various sources of which few are referenced in international bibliographic databases, which is why we opted for a narrative review. Secondly, our choice of how to define problematization, and which controversial moments to study, necessarily led us to showcase certain elements and salient actors to the detriment of others.

\section{CONCLUSION}

Are there any unique characteristics of research in France on homosexuality and HIV/AIDS? If we look at the issues studied as a whole, the answer is no. However, if we are interested in the 
way they were approached and envisioned as research questions, the answer is yes. As in numerous other countries, the advent of HIV/AIDS has represented a historic opportunity for financing studies on homosexuality and gender identity. In the social sciences of health, the epidemic has also played a large role in developing research on the experience of sickness (Pierret, 2007), the mobilization of sick populations, and the health system. The two largest challenges for research on homosexuality and HIV/AIDS are the capacity to understand the sociohistoric evolution of prevention among gay men (Méthy, Velter, Semaille, \& Bajos, 2015), and the capacity to convince those providing funding of the importance of examining the social, cultural, and political dimensions of risk in the era of treatment as prevention. As evidenced by the emergence of chemsex, the health issues surrounding gay men are multiple and evolving, and this diversity is a challenge for public health actors and social science researchers.

Finally, the increased presence of biomedical approaches in the reduction of risk of transmitting HIV does not signify that social sciences studies on sexual and preventive practices, representations and significations of sexuality, or political issues around prevention are obsolete (Nguyen, Bajos, Dubois-Arber, O’Malley, \& Pirkle, 2011). Firstly, these two approaches are not incompatible: they are complimentary. Secondly, the process of medicalization and prevention raises new social and political issues: failure to properly take one's medication; negotiating with one's partner; targeting of certain groups with public policy; allocation of resources; inequalities between the Global North and South, etc. Biomedicalization therefore challenges existing individual and collective behaviors towards HIV. For this reason, analysis from the social sciences remains indispensable to understanding the evolution of the epidemic, particularly in the gay community.

Acknowledgment: Translated by Michael Hawrysh. 


\section{REFERENCES}

Adam, P. (2003). HIV treatments optimism among gay men: An international perspective. Journal of Acquired Immune Deficiency Syndromes, 32, 545-550.

Adam, P., Hauet, E., \& Caron, C. (2001). Recrudescence des prises de risque et des MST parmi les gays: résultats préliminaires de l'Enquête presse gay 2000 [Increase in risk taking and STI among gay men: First results of Enquête Presse Gay 2000]. Paris: InVS, ANRS-DGS Report.

Adam, P., \& Schiltz, M.A. (1995). Reputedly effective risk reduction strategies and gay men. In P. Aggleton, P. Davies, G. Hart (Eds.), AIDS, safety, sexuality and risk, (pp. 1-20) London: Taylor and Francis.

Altman, D. (1984). AIDS: The politicization of an epidemic. Socialist Review, 78, 93-109.

Awondo, P., Geschiere, P., \& Reid, G. (2012). Homophobe Africa? Toward a more nuanced view, African Studies Review, 55, 145-168.

Bajos N. (1997). Social factors and the process of risk construction in HIV sexual transmission. AIDS Care, 9, 227-237.

Bajos, N., \& Bozon, M. (Eds.). (2008). Enquête sur la sexualité en France. Pratiques, genre et santé [Survey on sexuality in France. Practices, gender and health]. Paris: Éditions La Découverte.

Bajos, N., Bozon, M., Bletzer, N., Laborde, C., Andro, A., Ferrand, M., et al. (2010). Changing trends in sexual behaviours: From secular trends to public health policies. AIDS, 24, 1185-1191.

Bajos, N., Bozon, M., Ferrand, M., Giami, A., \& Spira, A. (Eds.). (1998). La sexualité aux temps du Sida [Sexuality in the era of AIDS]. Paris: Presses Universitaires de France.

Berg, R. (2009), Barebacking: A review of the literature. Archives of Sexual Behavior, 38, 754-764

Bochow, M., Chiarotti, F., Davies, P., Dubois-Arber, F., Dür, W., Fouchard, J., et al. (1994). Sexual behaviour of gay and bisexual men in eight european countries. AIDS Care, 6, 533-49. 
Bouhnik, A.D., Préau, M., Schiltz, M.A., Lert, F., Obadia, Y., Spire, B., \& VESPA Study Group. (2007). Unprotected sex in regular partnerships among homosexual men living with HIV: A comparison between sero-nonconcordant and seroconcordant couples (ANRS-EN12-VESPA Study). AIDS, 21, S43-48.

Bouhnik, A.D., Préau, M., Schiltz, M.A., Peretti-Watel, P., Obadia, Y., Lert, F., et al. (2006). Unsafe sex with casual partners and quality of life among HIV-infected gay men: Evidence from a large representative sample of outpatients attending French hospitals (ANRS-EN12-VESPA). Journal of Acquired Immune Deficiency Syndrome, 42, 597-603.

Broqua, C. (2006). Agir pour ne pas mourir! Act Up, les homosexuels et le sida [Acting not to die! Act Up, homosexuals and AIDS], Paris: Presses de Sciences Po.

Bozon, M., \& Doré, V. (Ed.). (2007). Sexualité, relations et prévention chez les homosexuels masculins. Un nouveau rapport au risque [Sexuality, relationships and prevention among homosexuals. A new perspective on risk]. Paris: Éditions ANRS.

Broqua, C. (2013). Male homosexuality in Bamako: a cross-cultural and cross-historical comparative perspective. In S.N. Nyeck, \& M. Epprecht (Eds.), Sexual Diversity in Africa: Politics, Theory, and Citizenship (pp. 208-224). Montréal: McGill-Queen’s University Press.

Broqua, C., Lert, F., \& Souteyrand, Y. (Ed.). (2003). Homosexualités au temps du sida. Tensions sociales et identitaires [Homosexualities in era of AIDS. Social and identity tensions]. Paris: Éditions ANRS.

Calvez, M. (2004). La prévention du sida. Les sciences sociales et la définition des risques [AIDS prevention. Social sciences and the definition of risks]. Rennes: Presses Universitaires de Rennes. 
Calvez, M., Schiltz, M.A., \& Souteyrand, Y. (Eds.). (1996). Les homosexuels face au sida. Rationalités et gestions des risques [Homosexuals facing AIDS. Rationalities and risk management]. Paris: Éditions ANRS.

Caron, D. (2001). AIDS in French culture. Social ills, literary cures. Madison: The University of Wisconsin Press.

Champenois, K., Le Gall, J.M., Jacquemin, C., Jean, S., Martin, C., Rios, L., et al. (2012). ANRSCOM'TEST: Description of a community-based HIV testing intervention in non-medical settings for men who have sex with men. BMJ Open, 2. http://dx.doi.org/10.1136/bmjopen$\underline{2011-000693}$

Chetcuti, N., Bletzer, N., Méthy, N., Laborde, C., Velter, A., Bajos, N., \& CSF Group. (2013). Preventive care's forgotten women: life course, sexuality, and sexual health among homosexually and bisexually active women in France. Journal of Sex Research, 50, 587-597.

Courduriès, J. (2007). Conjugalité et prévention du sida chez les gays [Conjugality and AIDS prevention among gay men]. In M. Bozon \& V. Doré (Eds.), Sexualité, relations et prévention chez les homosexuels masculins. Un nouveau rapport au risque (pp. 45-55). Paris: Éditions ANRS.

Davies, P. (1992). On relapse: Recidivism or rational response? In P., Aggleton, P. Davies \& G. Hart (Eds.) AIDS, rights, risk and reason (pp. 133-141). London: The Falmer Press,

De Busscher, P.O. \& Broqua, C. (2003). La crise de la normalisation: expériences et conditions sociales de l'homosexualité en France [The crisis of normalisation : experiences and social conditions of homosexuality in France]. In C. Broqua, F. Lert, \& Y. Souteyrand (Eds.). Homosexualités au temps du sida. Tensions sociales et identitaires (pp. 19-33). Paris: Éditions ANRS. 
De Busscher, P.O., Mendès-Leite, R., \& Proth, B. (1999). Lieux de rencontre et backrooms. Actes de la Recherche en Sciences Sociales. 128, 24-28.

Deschamps, C. (2002). Le miroir bisexuel. Paris: Éditions Balland.

Dodier, N. (2003). Leçons politiques de l'épidémie de sida [Political lessons from AIDS epidemic]. Paris: Éditions EHESS.

Elford, J. (2006). Changing patterns of sexual behaviour in the era of highly active antiretroviral therapy. Current Opinion in Infectious Disease, 19, 26-32.

Foucault, M. (1998). Polemics, politics and problematizations. In Essential Works of Foucault, edited by Rabinow, P., Vol. 1, New-York: The New Press.

Fournier, S., \& Escots, S. (2010). Homosexualité masculine et usages de substances psychoactives en contextes festifs gays [Homosexuality and drug use in gay venues]. Paris: OFDT Report.

Gagnon, J. (1988). Sex research and sexual conduct in the era of AIDS. Journal of Acquired Immune Deficiency Syndromes, 1(6), 593-601

Gaissad, L. (2005). From nightlife conventions to daytime hidden agendas: Dynamics of urban sexual territories in the south of France. Journal of Sex Resarch, 42, 20-27.

Gaissad, L. (2013). La Démence ou la dépense? Le circuit festif gay entre consommation et consummation [Démence or expanse? Gay circuit, between consumption and consummation]. Ethnologie Française, 43, 409-416.

Giami, A. \& Beaubatie, E. (2014). Gender identification and sex reassignment surgery in the trans population: A survey study in France. Archive of Sexual Behavior, 43, 1491-1501.

Giami, A., \& Schiltz, M.A. (1996). Representations of sexuality and relations between partners: Sex research in France in the era of AIDS. Annual Review of Sex Research, 7, 125-157.

Girard, G. (2013). Les homosexuels et le risque du sida. Individu, communauté et prévention. Rennes, Presses Universitaires de Rennes. 
Girard, G. (2016). HIV risk and sense of community: French gay male discourses on barebacking. Culture, Health \& Sexuality, 18, 15-29.

Giraud, M. (1997). Entre particularités épidémiologiques et spécificités culturelles: l'enquête sur les comportements sexuels aux Antilles et en Guyane française (ACSAG). Sciences sociales et santé, 15, 73-95.

Gning, N. (2013). Les motifs de l'illégitimité sociale de l'homosexualité au Sénégal. Africultures, 96, 22-39.

Goshn, J., Leruez-Ville, M., Blanche, J., Delobelle, A., Beaudoux, C., Mascard, L., et al. (2014). HIV-1 DNA levels in peripheral blood mononuclear cells and cannabis use are associated with intermittent HIV shedding in semen of men who have sex with men on successful antiretroviral regimens. Clinical infectious disease, 58, 1763-1770.

Greacen, T., Friboulet, D., Fugon, L., Hefez, S., Lorente, N., \& Spire, B. (2012). Access and use of unauthorised online HIV self-tests by internet-using French-speaking men who have sex with men. Sexual Transmitted Infections, 88, 368-374.

Hankins, C., \& Zalduondo, B. (2010). Combination prevention: A deeper understanding of effective HIV prevention. AIDS, 24, S70-S80.

Jin, F., Crawford, J., Prestage, G.P., Zablotska, I., Imrie, J., Kippax, S.C., et al. (2009). Unprotected anal intercourse, risk reduction behaviours, and subsequent HIV infection in a cohort of homosexual men. AIDS, 23, 243-252.

Kippax, S., Crawford, J., Davis, M., Rodden, P., \& Dowsett, G. (1993). Sustaining safer sex: A longitudinal study of a sample of homosexual men. AIDS, 7, 257-263.

Kippax, S., \& Race, K. (2003). Sustaining safer sex: Twenty years on. Social Science \& Medicine, 57, $1-12$. 
Lagrange, H., \& Lhomond, B. (Ed.). (1997). L'entrée dans la sexualité: les comportements des jeunes dans le contexte du sida [The entering in sexuality: Youth sexual behaviours in context of AIDS]. Paris: Éditions La Découverte.

Laurindo da Silva, L. (1999). Travestis and gigolos. Male prostitution and HIV prevention in France. In P. Aggleton (Ed.) Men who sell sex. International perspectives on male sex work and HIV/AIDS (pp. 41-60). London: UCL Press,.

Léobon, A., \& Frigault, L.R. (2007). La sexualité bareback: d'une culture de sexe à la réalité des prises de risque. [Bareback sex: From a sexual culture to the reality of risk-taking]. In Bozon, M., \& Doré, V., Sexualité, relations et prevention chez les homosexuels masculins, Paris: Éditions ANRS

Léobon, A., Velter, A., Engler, K., Drouin, M.C., \& Otis, J. (2011). A relative profile of HIVnegative users of French websites for men seeking men and predictors of their regular risktaking: A comparison with HIV-positive users. AIDS Care, 23, 25-34.

Lerch, A. (2007). Transparence, verbalisation, silence: la gestion de l'information quant aux prises de risque dans les couples gay multipartenaires [Transparence, verbalisation, silence: Information management and risk taking in gay couples]. In M. Bozon, \& V. Doré, (Eds.), Sexualité, relations et prévention chez les homosexuels masculins. Un nouveau rapport au risque (pp. 57-67). Paris: Éditions ANRS.

Lert, F. (2000). Advances in HIV treatment and prevention: Should treatment optimism lead to prevention pessimism? AIDS Care, 12, 745-755.

Lert, F., \& Pialoux, G. (2010). Prévention et réduction des risques dans les groupes à haut risque visà-vis du VIH et des IST. Paris: DGS Report. 
Lert, F., Sitta, R., Bouhnik, A.D., Dray-Spira, R., \& Spire, B. (2010). HIV-positive men who have sex with men: Biography, diversity in lifestyles, common experience of living with HIV. ANRSEN12 VESPA Study. AIDS Care, 22, 71-80.

Lert, F., \& Souteyrand, Y. (1999). Séropositivité, vie sexuelle et risque de transmission du VIH [Seropositivity, sexual life and risk of HIV transmission]. Paris: Éditions ANRS.

Le Talec, J.Y. (2007). Bareback et construction sociale du risque lié au VIH chez les hommes gay [Barebacking and social construction of HIV risk among gay men]. In M. Bozon \& V. Doré, (Eds.), Sexualité, relations et prévention chez les homosexuels masculins. Un nouveau rapport au risque (pp. 71-86). Paris: Éditions ANRS.

Le Talec, J.Y. (2013). When raw sex turns to a raw deal... Taking the opportunity to think about sex? Interviews with HIV-positive gay men diagnosed with acute hepatitis C. Culture, Health and Sexuality, 15, 1133-1147.

Le Vu, S., Le Strat, Y., Barin, F., Pillonel, J., Cazein, F., Bousquet, et al. (2010). Population-based HIV-1 incidence in France, 2003-2008: A modelling analysis. Lancet Infectious Diseases, 10, $682-687$.

Lisandre, H. (1996). Les facteurs inconscients de la contamination par voie sexuelle [Inconscious factors of sexual transmission]. In M. Calvez, M.A. Schiltz \& Y. Souteyrand (Eds.). Les homosexuels face au sida. Rationalités et gestions des risques (pp. 77-87). Paris: Éditions ANRS

Lorente, N., Fugon, L., Carrieri, M.P., Andreo, C., Le Gall, J.M., Cook, E., et al. (2012). Acceptability of an 'on demand' pre-exposure prophylaxis trial among men who have sex with men living in France. AIDS Care, 24, 468-477.

Lorente, N., Preau, M., Vernay-Vaisse, C., Mora, M., Blanche, J., Otis, et al. (2013). Expanding access to non-medicalized community-based rapid testing to men who have sex with men: An 
urgent HIV prevention intervention (the ANRS-DRAG study), PLoS One, 8. https://doi.org/10.1371/journal.pone.0061225

Lorente, N., Suzan-Monti, M., Vernay-Vaisse, C., Mora, M., Blanche, J., Fugon, L., et al. (2012). Empowering HIV testing as a prevention tool: targeting interventions for high-risk men who have sex with men. AIDS Care, 24, 1039-1045.

Marcellin, F., Lorente, N., Demoulin, B., Carrieri, M.P., Suzan-Monti, M., Roux, P., et al. (2015). Comparison of risks factors in HIV-infected men who have sex with men, coinfected or not with heaptitis C virus (ANRS VESPA2 French cross-sectional national survey). Sexually Transmitted Infections, 91, 21-23.

Marsicano, E., Dray-Spira, R., Lert, F., Aubrière, C., Spire, B., Hamelin, C. \& ANRS-Vespa2 Study Group. (2014). Multiple discriminations experienced by people living with HIV in France: Results from the ANRS-Vespa2 Study. AIDS Care, 26, S97-S106.

Mendès-Leite, R. (1995). Comment ou combien? La gestion des risques de transmission du sida, [How or how many? Risk management of AIDS transmission]. Quel Corps?, 47-48-49, 70-91. Mendès-Leite, R. (1998). Imaginary protection against AIDS. Journal of Psychology and Human Sexuality, 10, 103-122.

Mendès-Leite, R., \& de Zwart, O. (2000). Fighting the epidemic: social AIDS studies. In T. Sandfort, J. Schuyf, J. Duyvendak,, \& J. Weeks, Lesbian and Gay studies : An introductory, interdisciplinarity approach (pp. 195-214). London: SAGE publications

Méthy, N., Velter, A., Semaille, C. \& Bajos, N. (2015). Sexual behaviours of homosexual and bisexual men in France: A generational approach. PLoS One, 10. https://doi.org/10.1371/journal.pone.0123151 
Molina, J.M., Capitant C., Spire B., Pialoux G., Cotte L., Charreau I. et al. (2015). On-demand preexposure prophylaxis in men at high risk for HIV-1 infection. New England Journal of Medicine, 373, 2237-2246.

Nguyen, V.K., Bajos, N., Dubois-Arber, F., O’Malley, J., \& Pirkle, C. (2011). Remedicalising an epidemic: from HIV treatment as prevention to HIV treatment is prevention. AIDS, 25, 291293.

Patton, C. (1989). The AIDS industry: Construction of victims, volunteers and experts. In E. Carter \& S. Watney (Eds.) Taking liberties: AIDS and cultural politics (pp. 113-125). London: Serpent's Tail.

Pierret, J. (1996). Organisation et interprétation du temps chez les homosexuels contaminés par le virus du sida [Organization and understanding of time among HIV positive gay men]. In M. Calvez, M.A. Schiltz \& Y. Souteyrand (Eds.). Les homosexuels face au sida. Rationalités et gestions des risques (pp. 89-96). Paris: Éditions ANRS

Pierret, J. (2007). An analysis over time (1990-2000) of the experiences of living with HIV. Social Science \& Medicine, 65, 1595-605.

Pinell, P. (Ed.). (2002). Une épidémie politique: la lutte contre le SIDA en France, 1981-1996 [A political epidemic: AIDS mobilization in France, 1981-1996]. Paris: Presses Universitaires de France.

Pollak, M. (1988). Les homosexuels et le sida: sociologie d'une épidémie [Gay men and AIDS: Sociology of an epidemic]. Paris: Éditions AM Métailié.

Pollak, M., \& Schiltz, M.A. (1987). Identité sociale et gestion d'un risque de santé: les homosexuels face au sida [Social identity and health risk management: Homosexuals facing AIDS]. Actes de la Recherche en Sciences Sociales, 68, 77-102. 
Proth, B. (2002). Lieux de drague: scènes et coulisses d'une sexualité masculine. Toulouse: Éditions Octarès.

Rojas Castro, D., Coquelin, V., Sempé, S., Jablonski, O., Le Gall, J.M., Andreo, C., \& Spire, B. (2012). Barebacking and sexual health in the French setting: NoKondom Zone workshops. AIDS Care, 24, 1046-1051.

Rojas-Castro, D., \& Girard, G. (2015). Barebacking in France: From controversy to community ownership? An account of Zone NoKpote workshops conducted by AIDES in 2009. Sexualities, 18, 158-175.

Rosenbrock, R., Dubois-Arber, F., Moers, M., Pinell, P., Schaeffer, D., \& Setbon, M. (2000). The normalization of AIDS in Western countries. Social Science \& Medicine, 50, 1607-1629.

Schiltz, M.A. (1998). Not all men, situation, and actions are equal. Moving from a 100\% protection to a more realistic prevention practice. Journal of Psychology and Human Sexuality, 10, 19-35.

Schiltz, M.A. (2010). De la contingence à la carrière. Genre, Sexualité et Société, 4, DOI : $10.4000 /$ gss. 1618

Semaille, C., Barin, F., Bouyssou, A., Peytavin, G., Guinard, J., Le Vu, et al. (2013). High viral load among HIV-positive MSM attending gay venue: Implications for HIV transmission. Journal of Acquired Immune Deficiency Syndrome, 63, 122-124.

Stall, R., Hays, R., Waldo, C., Ekstrand, M., \& McFarland, W. (2000). The gay 90's: A review of research on sexual behavior and HIV risk among men who have sex with men. AIDS, 14, S101-S114.

Treichler, P. (1987). AIDS, homophobia and biomedical discourse: An epidemic of signification. Cultural Studies, 3, 263-305. 
Van de Ven, P., Prestage, G., French, J., Knox, S. \& Kippax, S. (1998). Increase in unprotected anal intercourse with casual partners among Sydney gay men in 1996-98. Australian and New Zealand Journal of Public Health, 22, 814-818.

Velter, A. (Ed.). (2007). Rapport Enquête Presse Gay 2004 [Enquête presse gay Report 2004]. SaintMaurice: ANRS-InVS.

Velter, A. (2013). Comportements sexuels entre hommes à l'ère de la prevention combinée - résultats de l'enquête presse gays et lesbiennes 2011 [Sexual behavior between men in the era of combination prevention-Results from the Gay and Lesbian Survey 2011, France]. Bulletin Epidémiologique Hebdomadaire, 39-40, 510-516.

Velter, A., Barin, F., Bouyssou, A., Guinard, J., Léon, L., Le Vu, S., et al. (2013). HIV prevalence and sexual risk behaviors associated with awarness of HIV status among men who have sex with men living in Paris, France. AIDS \& Behavior, 17, 1266-1278.

Velter, A., Bouyssou-Michel, A., Arnaud, A., \& Semaille, C. (2009). Do men who have sex with men use serosorting with casual partners in France? Results of a nationwide survey (ANRS-EN17Presse Gay 2004). Euro Surveillance, 14, 1-8.

Vörös, F. (2014). Raw fantasies. An interpretative sociology of what bareback porn does and means to French gay male audiences. In E. Lewis, R. Borba, B. Fabrico, \& D. Pinto (Eds.). Queering Paradigms IV (pp. 321-344). Oxford: Peter Lang,.

Wade, A., Larmarange, J., Diop, A., Diop, O., Gueye, K., Marra, A., et al. (2010). Reduction in risktaking behaviors among MSM in Senegal between 2004 and 2007 and prevalence of HIV and other STIs. ELIHoS project, ANRS12139. AIDS Care, 22, 409-414.

Welzer-Lang, D., Le Talec, J.Y., \& Tomolillo, S. (2000). Un mouvement gai dans la lutte contre le sida: les Scurs de la Perpétuelle Indulgence [A gay movement against AIDS: The sisters of perpetual indulgence]. Paris: Éditions L’Harmattan. 
